Génét. Sél. Evol., 1986, 18 (4), 405-416

\title{
Alcohol tolerance and Adh gene frequencies in European and African populations of Drosophila melanogaster
}

\author{
J.R. DAVID * , H. MERÇOT **, P. CAPY *, S.F. McEVEY * \\ and Jeanine VAN HERREWEGE *** \\ * Laboratoire de Biologie et Génétique Evolutives, C.N.R.S, F 91190 Gif-sur-Yvette \\ ** Laboratoire de Génétique des Populations, Université Paris VII, 2, place Jussieu, \\ F 75221 Paris Cedex 05 \\ *** Laboratoire de Biologie des Populations, Université Claude Bernard, F 69622 Villeurbanne
}

\begin{abstract}
Summary
Natural populations from France, several countries around the Mediterranean sea, tropical Africa and South Africa were investigated for ethanol tolerance and allelic frequencies at the $A d h$ locus. Both traits exhibited a clinal pattern, i.e. an increase of tolerance and of the frequency of the $A d h-F$ allele with latitude. Larvae exhibited variations in tolerance similar to those previously known in adults, in agreement with the hypothesis that in nature larvae could be the effective target of ethanol selection. Between Europe and Africa, the latitudinal cline for the Adh locus is not linear, but rather exhibits a sigmoid shape with a very steep slope between 30 and $40^{\circ}$ of latitude. Populations from South Africa are conveniently included in this general shape. Both types of clines seem to have some adaptive significance. However, the very high correlation $(0.89)$ between variations of ethanol tolerance and of $A d h-F$ allele is not a demonstration of a causal relationship between the two traits.
\end{abstract}

Key words : Drosophila melanogaster, allozymes, Adh polymorphism, alcohol tolerance, latitudinal clines.

\section{Résumé}

Tolérance à l'alcool et fréquences alléliques de l'Adh chez des populations européennes et africaines de Drosophila melanogaster.

Des populations naturelles provenant de France, du pourtour de la Méditerranée, d'Afrique tropicale et d'Afrique du Sud ont été étudiées pour leur tolérance à l'alcool et les fréquences alléliques du locus $A d h$. Les 2 caractères montrent une variation clinale, c'est-à-dire une augmentation de la tolérance et de la fréquence de l'allèle $A d h-F$ avec la latitude. Les larves présentent des variations de la tolérance analogues à celles déjà connues chez les adultes, ce qui est en accord avec l'hypothèse selon laquelle, dans la nature, les larves seraient la véritable cible de la sélection exercée par l'éthanol. Entre l'Europe et l'Afrique, le cline pour le locus de l'Adh n'est pas linéaire mais il présente plutôt une forme sigmoïde, avec une pente abrupte entre 30 et 40 degrés de latitude. Les populations du sud de l'Afrique se disposent convenablement sur cette courbe sigmoïde. Les 2 types de clines semblent tous deux avoir une signification adaptative. Cependant, la très forte corrélation $(0,89)$ observée entre les variations de la tolérance à l'alcool et celles de l'allèle $A d h-F$ ne prouve pas l'existence d'une relation causale entre les 2 caractères.

Mots clés: Drosophila melanogaster, allozymes, polymorphisme du locus Adh, tolérance à l'alcool, clines de latitude. 


\section{Introduction}

Evidence from a set of biogeographic and phylogenetic studies strongly suggests that $D$. melanogaster, as well as the 7 other species belonging to the same subgroup, originated in tropical Africa (see LEMEUNIER et al., 1986, for a review). Ancestral populations are thus found in the Afrotropical region while other continents and especially America and Australia appear to have been colonized only a few centuries ago, through human transportation.

With respect to allozyme frequencies, D. melanogaster is the most differentiated among its geographic populations. Several genes exhibit clear latitudinal clines among which the $A d h$ locus is probably the most studied (Johnson \& Schaffer, 1973; Voelker et al., 1978 ; DAVID, 1982 ; OAKeshotT et al., 1982 ; Singh et al., 1982). Alcohol dehydrogenase, produced by the $A d h$ gene, is a key enzyme for ethanol tolerance in Drosophila (DAvid et al., 1976). Alcohol tolerance of adults also exhibits a clear latitudinal cline between equatorial Africa and Europe (DAvID \& BocQueT, 1975). However comparative interspecific studies have shown that environmental alcohol, as a selective ecological factor, is more likely to act upon larvae than upon adults (DAvid \& Van Herrewege, 1983).

The present study was undertaken for several, complementary purposes. First, to analyse the relationship between larval and adult tolerance among geographic populations. Second, to get more information about $A d h$ allelic frequencies between Europe and the African continent, and especially for populations around the mediterranean sea and in the southern hemisphere. Third, to correlate $A d h$ frequencies and alcohol tolerance since, up to now, such measurements have been done independently and often on different populations.

\section{Materials and methods}

\section{A. Drosophila populations}

Wild living females, collected with a fermenting bait, were isolated in culture vials to initiate isofemale lines. These lines were used to estimate $A d h$ allelic frequencies. For measuring ethanol tolerance, a mass culture was established by pooling the lines. For any population, the minimum number of different lines was 10 , but in most cases ranged around 30 or more.

\section{B. Adh allelic frequencies}

After the lines were established, 2 individuals were taken at random from each of them and checked for their Adh genotype, using starch gel electrophoresis with the buffer system of Poulik (1957). All populations segregated for the 2 common alleles, fast $(F)$ and slow $(S)$.

\section{Alcohol tolerance}

Ethanol tolerance was assayed either on adult flies or on larvae. For the study of adults, flies were put in air tight plastic vials in the presence of various ethanol 
concentrations, and mortality scored after 2 days of treatment at $25^{\circ} \mathrm{C}$ (see DAvid et al., 1974, for more details). For testing the larvae, alcohol was incorporated in a killed yeast-sucrose medium (dry yeast $70 \mathrm{~g}$, sucrose $70 \mathrm{~g}$, agar $20 \mathrm{~g}$, nipagine $6 \mathrm{~g}$, water $1 \mathrm{l}$ ) at a moderate temperature $\left(45^{\circ} \mathrm{C}\right)$ to limit the evaporation. Vials were stored at $5{ }^{\circ} \mathrm{C}$ and used 18 hours later. For each concentration 6 replicate vials were made, each containing 50, 0-3 hour-old eggs. At the end of development, the emerged adults were counted and a percentage of «mortality » calculated. Since this percentage included unhatched eggs and natural larval and pupal mortality, the percentages obtained on alcoholic food were corrected by subtracting the control value. A median lethal concentration (L.C. 50) was computed after angular transformation of percentages and logarithmic transformation of ethanol concentrations. This procedure provided not only the L.C. 50 value but also an estimate of its standard deviation.

For the adults, no correction was necessary since control mortality was nil. The L.C. 50 was estimated graphically as shown in figure 1 , by considering the abcissa at which the mortality curve crosses the line of $50 \mathrm{p}$. 100. The calculation procedure provided almost identical results.

\section{Results}

\section{A. Ethanol tolerance of larvae and adults}

Results, expressed as the L.C. 50 in percent ethanol, are given in tables 1 and 2 for larvae and adults respectively. Inspection of the data shows a great variability between distant populations and a better homogeneity between populations from the

TABLE 1

Larval ethanol tolerance and Adh-F frequency in 15 natural populations of D. melanogaster ( $p:$ frequency ; $n:$ number of genes).

\begin{tabular}{|c|c|c|c|c|c|}
\hline \multirow{2}{*}{ Country } & \multirow{2}{*}{ Locality } & \multirow{2}{*}{ Latitude } & \multicolumn{2}{|c|}{$A d h^{\mathrm{F}}$ frequency } & \multirow{2}{*}{$\begin{array}{l}\text { Ethanol } \\
\text { tolerance }\end{array}$} \\
\hline & & & $p$ & $\mathbf{n}$ & \\
\hline France $\ldots \ldots$ & $\begin{array}{l}\text { Venteuil } \\
\text { Châteaubriand } \\
\text { Ménétréol } \\
\text { Villeurbanne } \\
\text { Bonnac-la-Côte } \\
\text { Les Fumades } \\
\text { Banyuls }\end{array}$ & $\begin{array}{l}49.0 \mathrm{~N} \\
47.4 \mathrm{~N} \\
47.2 \mathrm{~N} \\
45.7 \mathrm{~N} \\
45.5 \mathrm{~N} \\
43.3 \mathrm{~N} \\
42.3 \mathrm{~N}\end{array}$ & $\begin{array}{l}0.953 \\
0.991 \\
0.949 \\
0.932 \\
0.938 \\
0.974 \\
0.918\end{array}$ & $\begin{array}{l}300 \\
212 \\
216 \\
236 \\
216 \\
466 \\
282\end{array}$ & $\begin{array}{l}17.0 \pm 0.3 \\
16.6 \pm 0.4 \\
16.7 \pm 0.3 \\
15.4 \pm 0.5 \\
15.0 \pm 0.2 \\
16.0 \pm 0.2 \\
18.0 \pm 0.7\end{array}$ \\
\hline Tunisia . & Bou-Argoub & $36.2 \mathrm{~N}$ & 0.873 & 150 & $16.8 \pm 0.3$ \\
\hline Bénin & Cotonou & $6.2 \mathrm{~N}$ & 0.016 & 614 & $7.6 \pm 0.1$ \\
\hline Ivory Coast $\ldots$ & $\begin{array}{l}\text { Lamto } \\
\text { Taï }\end{array}$ & $\begin{array}{l}6.1 \mathrm{~N} \\
5.6 \mathrm{~N}\end{array}$ & $\begin{array}{l}0.090 \\
0.266\end{array}$ & $\begin{array}{r}44 \\
124\end{array}$ & $\begin{array}{l}9.6 \pm 0.3 \\
9.2 \pm 0.1\end{array}$ \\
\hline Congo & $\begin{array}{l}\text { Brazzaville } \\
\text { Dimonika }\end{array}$ & $\begin{array}{l}4.2 \mathrm{~S} \\
4.0 \mathrm{~S}\end{array}$ & $\begin{array}{l}0.064 \\
0.012\end{array}$ & $\begin{array}{r}156 \\
78\end{array}$ & $\begin{array}{l}8.5 \pm 0.2 \\
6.5 \pm 0.2\end{array}$ \\
\hline South Africa & $\begin{array}{l}\text { Johannesburg } \\
\text { Cape Town }\end{array}$ & $\begin{array}{l}26.2 \mathrm{~S} \\
33.5 \mathrm{~S}\end{array}$ & $\begin{array}{l}0.337 \\
0.519\end{array}$ & $\begin{array}{r}92 \\
104\end{array}$ & $\begin{array}{l}10.2 \pm 0.2 \\
11.8 \pm 0.3\end{array}$ \\
\hline
\end{tabular}



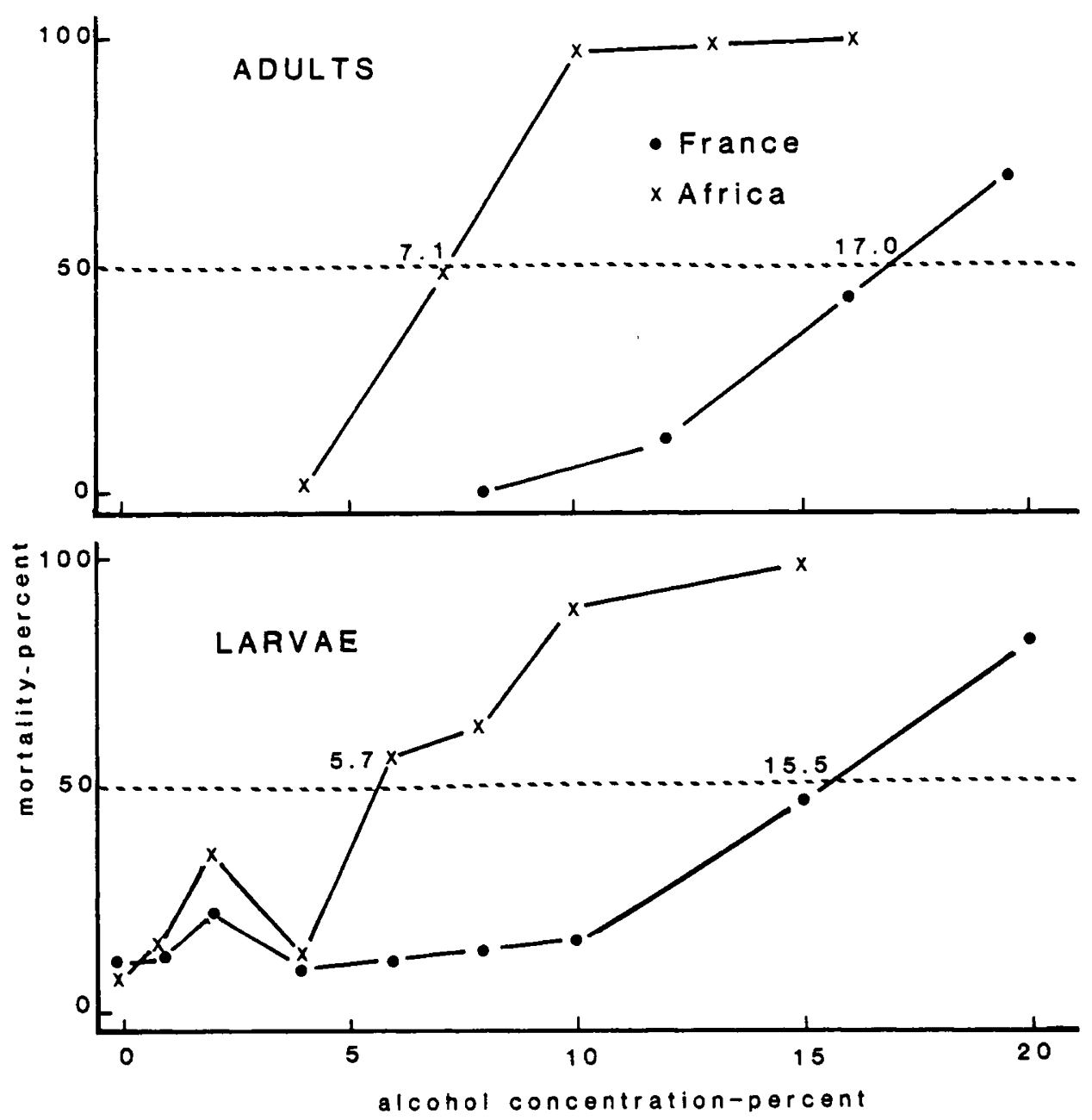

Fig. 1

Comparison of larval and adult ethanol tolerance in 2 D. melanogaster populations from France and tropical Africa (Congo). The intersection of the mortality curves with an horizontal line at $50 \mathrm{p} .100$ allows a graphic estimate of the LC 50.

same geographic area. Although the experimental techniques were quite different, values measured on larvae and adults are surprisingly very similar. This conclusion is exemplified by the mortality curves of figure 1 and by statistical analysis. For 9 populations, the studies were done simultaneously on larvae and adults, providing a correlation $r=0.89$ and a regression slope of 1.07 . We may also point out that, for French strains from various origins, the average L.C. 50 is for larvae $16.39 \pm 0.38$ $(n=7)$ and for adults $17.06 \pm 0.23(n=9)$ : these values are very close and not statistically different. 


\section{B. Adh allelic frequencies}

Frequencies of the $\mathrm{F}$ allele are given in tables 1 and 2 and also shown on the map figure 2. We confirm that the $F$ allele is predominant in European populations, as already shown by several investigators (Girard et al., 1977 ; David, 1982 ; CharlesPalabost et al. 1985) while it is rare in tropical Africa, as already found (DAvID, 1982). Interestingly, South African populations harbour more $F$ alleles than tropical ones.

\section{TABLE 2}

Adult ethanol tolerance and Adh-F frequency in 32 natural populations of $\mathrm{D}$. melanogaster ( $p:$ frequency; $n:$ number of genes).

\begin{tabular}{|c|c|c|c|c|c|}
\hline \multirow{2}{*}{ Country } & \multirow{2}{*}{ Locality } & \multirow{2}{*}{ Latitude } & \multicolumn{2}{|c|}{$A d h^{F}$ frequency } & \multirow{2}{*}{$\begin{array}{l}\text { Ethanol } \\
\text { tolerance }\end{array}$} \\
\hline & & & p & $\mathbf{n}$ & \\
\hline France & $\begin{array}{l}\text { Venteuil } \\
\text { Draveil } \\
\text { Quimperlé } \\
\text { Bully } \\
\text { Villeurbanne } \\
\text { Dieulefit } \\
\text { Malaucène } \\
\text { Porquerolles } \\
\text { Moulis }\end{array}$ & $\begin{array}{ll}49.0 \mathrm{~N} \\
48.4 \mathrm{~N} \\
47.5 \mathrm{~N} \\
45.8 \mathrm{~N} \\
45.7 \mathrm{~N} \\
44.8 \mathrm{~N} \\
44.1 \mathrm{~N} \\
43.0 \mathrm{~N} \\
42.6 \mathrm{~N}\end{array}$ & $\begin{array}{l}0.953 \\
0.931 \\
0.920 \\
0.930 \\
0.932 \\
0.938 \\
0.936 \\
0.900 \\
0.953\end{array}$ & $\begin{array}{r}300 \\
58 \\
112 \\
256 \\
236 \\
504 \\
252 \\
40 \\
.360\end{array}$ & $\begin{array}{l}16.1 \\
17.9 \\
16.4 \\
16.4 \\
17.3 \\
17.3 \\
17.5 \\
17.8 \\
16.8\end{array}$ \\
\hline U.S.S.R. . . & Magarach & $45.0 \mathrm{~N}$ & 0.975 & 40 & 20.1 \\
\hline Greece ..... & Athens & $37.6 \mathrm{~N}$ & 0.813 & 112 & 17.3 \\
\hline Spain ........ & Sevilla & $37.2 \mathrm{~N}$ & 0.733 & 60 & 18.5 \\
\hline Tunisia $\ldots \ldots \ldots$ & $\begin{array}{l}\text { Bizerte } \\
\text { Nasrallah } \\
\text { Chebika }\end{array}$ & $\begin{array}{l}37.1 \mathrm{~N} \\
35.4 \mathrm{~N} \\
34.1 \mathrm{~N}\end{array}$ & $\begin{array}{l}0.885 \\
0.953 \\
0.935\end{array}$ & $\begin{array}{r}78 \\
106 \\
122\end{array}$ & $\begin{array}{l}13.3 \\
16.6 \\
14.5\end{array}$ \\
\hline Algeria & Tizi-Ouzou & $36.5 \mathrm{~N}$ & 0.893 & 56 & 18.3 \\
\hline Morocco $\ldots .$. & $\begin{array}{l}\text { Rabat } \\
\text { Casablanca }\end{array}$ & $\begin{array}{l}34.0 \mathrm{~N} \\
33.4 \mathrm{~N}\end{array}$ & $\begin{array}{l}0.750 \\
0.810\end{array}$ & $\begin{array}{l}52 \\
84\end{array}$ & $\begin{array}{l}13.5 \\
10.6\end{array}$ \\
\hline Irak & Bagdad & $33.2 \mathrm{~N}$ & 0.880 & 100 & 13.4 \\
\hline Cameroon .. & Ngaoundéré & $7.2 \mathrm{~N}$ & 0.005 & 396 & 8.6 \\
\hline Bénin $\ldots \ldots \ldots$ & $\begin{array}{l}\text { Calavi } \\
\text { Cotonou }\end{array}$ & $\begin{array}{l}6.2 \mathrm{~N} \\
6.2 \mathrm{~N}\end{array}$ & $\begin{array}{l}0.025 \\
0.016\end{array}$ & $\begin{array}{l}360 \\
614\end{array}$ & $\begin{array}{l}6.1 \\
8.6\end{array}$ \\
\hline Ivory-Coast & $\begin{array}{l}\text { Lamto } \\
\text { Taï }\end{array}$ & $\begin{array}{l}6.1 \mathrm{~N} \\
5.6 \mathrm{~N}\end{array}$ & $\begin{array}{l}0.090 \\
0.266\end{array}$ & $\begin{array}{r}44 \\
124\end{array}$ & $\begin{array}{l}6.1 \\
9.3\end{array}$ \\
\hline Tanzania & Nyenges & $2.5 \mathrm{~N}$ & 0.018 & 112 & 8.6 \\
\hline Congo & $\begin{array}{l}\text { Brazzaville } \\
\text { Dimonika } \\
\text { Madibou }\end{array}$ & $\begin{array}{l}4.2 \mathrm{~S} \\
4.0 \mathrm{~S} \\
4.0 \mathrm{~S}\end{array}$ & $\begin{array}{l}0.064 \\
0.012 \\
0.063\end{array}$ & $\begin{array}{r}156 \\
778 \\
96\end{array}$ & $\begin{array}{l}6.5 \\
7.1 \\
6.9\end{array}$ \\
\hline Swaziland. & Mbuluzi & $26.1 \mathrm{~S}$ & 0.100 & 40 & 9.0 \\
\hline South Africa $\ldots \ldots$ & $\begin{array}{l}\text { Johannesburg } \\
\text { Cape Town } \\
\text { Harkerville }\end{array}$ & $\begin{array}{l}26.2 \mathrm{~S} \\
33.5 \mathrm{~S} \\
34.0 \mathrm{~S}\end{array}$ & $\begin{array}{l}0.337 \\
0.519 \\
0.264\end{array}$ & $\begin{array}{r}92 \\
104 \\
72\end{array}$ & $\begin{array}{l}11.9 \\
14.1 \\
14.3\end{array}$ \\
\hline
\end{tabular}




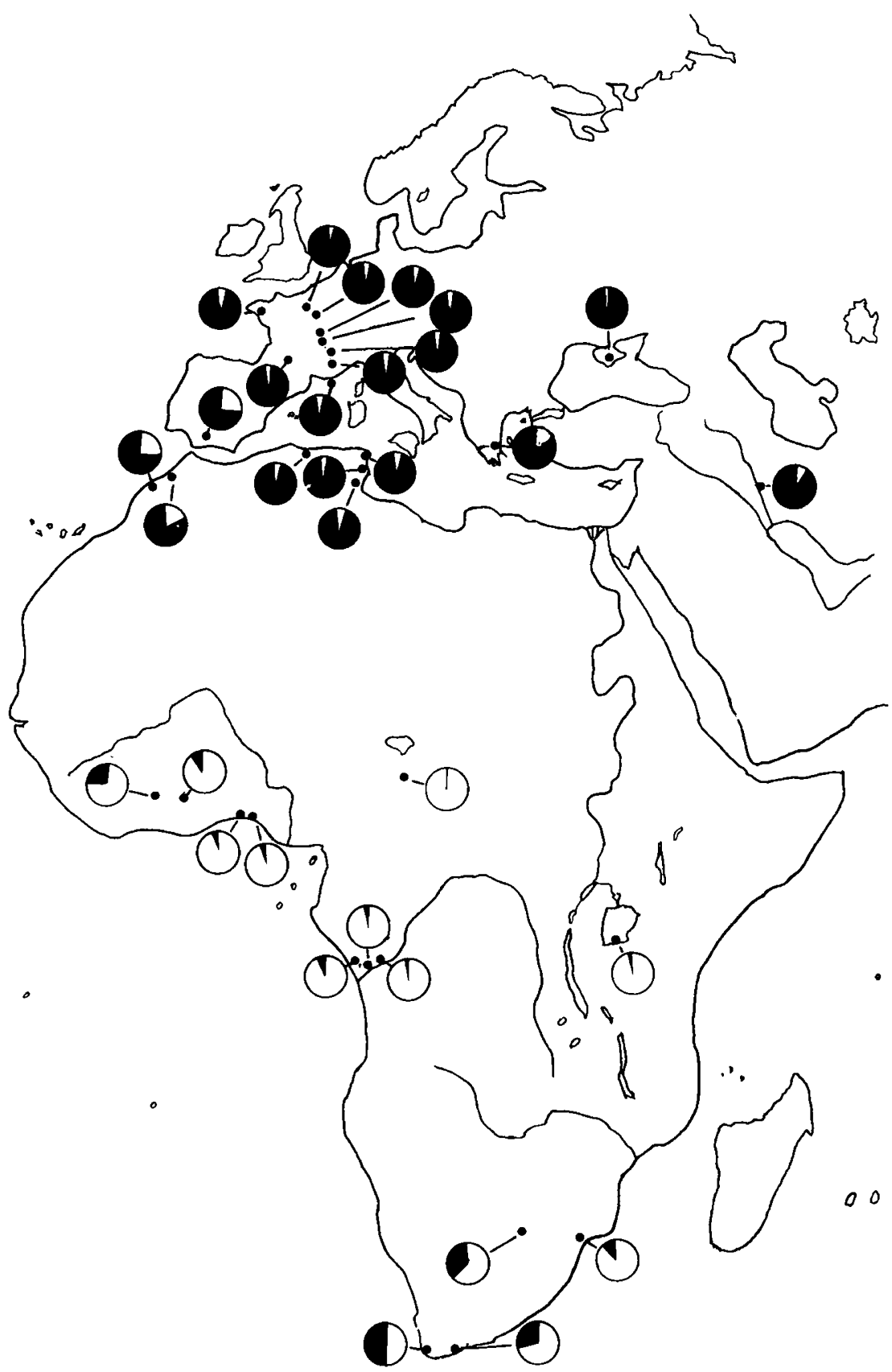

FIG. 2

Geographic localization and Adh allelic frequencies of the 32 populations studied in table 2. The frequency of the $\mathrm{F}$ allele is given by the black area of each circle. 


\section{Relationships between biological traits and geographic or climatic data}

In this study we have considered 2 climatic parameters, i.e. mean annual temperature and rainfall, and 2 geographic data, i.e. latitude and longitude. Altitude was not considered since, with few exceptions (e.g. Johannesburg) most populations were collected at a low elevation. The analysis was done using the data collected on adults only and the results are presented in table 3.

\section{TABLE 3}

Correlation (r), regression slope (b) and ordinate (a) between biological variables (ethanol tolerance and Adh-F frequency) and geographic and climatic correlates. Calculations made for the 32 populations shown in table 2. The significance threshold of $r(p=0.05)$ is 0.349 .

\begin{tabular}{|c|c|c|c|}
\hline Variables & \multirow{2}{*}{$\mathbf{r}$} & \multirow{2}{*}{$b$} & \multirow{2}{*}{ a } \\
\hline$y-x$ & & & \\
\hline $\begin{array}{l}\text { temperature - latitude } \ldots \ldots \ldots \ldots \\
\text { rainfall - latitude } \ldots \ldots \ldots \ldots \ldots \\
\text { rainfall - temperature } \ldots \ldots \ldots \ldots\end{array}$ & $\begin{array}{r}0.911 \\
-0.661 \\
0.453\end{array}$ & $\begin{array}{r}-0.31 \pm 0.03 \\
-1.55 \pm .32 \\
3.14 \pm 1.12\end{array}$ & $\begin{array}{r}27.11 \pm .41 \\
125.14 \pm 5.19 \\
23.06 \pm 6.17\end{array}$ \\
\hline $\begin{array}{l}\text { tolerance }- \text { temperature } \ldots \ldots \ldots \ldots \\
\text { Adh-F }- \text { temperature } \ldots \ldots \ldots \ldots \\
\text { tolerance }- \text { rainfall } \ldots \ldots \ldots \ldots \\
\text { Adh-F }- \text { rainfall } \ldots \ldots \ldots \ldots \\
\text { tolerance }- \text { longitude } \ldots \ldots \ldots \ldots \ldots \\
\text { Adh-F }- \text { longitude } \ldots \ldots \ldots \ldots \ldots\end{array}$ & $\begin{array}{r}-0.823 \\
-0.770 \\
-0.646 \\
-0.701 \\
-0.053 \\
0.179\end{array}$ & $\begin{array}{l}-0.65 \pm 0.08 \\
-5.46 \pm 0.82 \\
-0.07 \pm 0.02 \\
-0.72 \pm 0.13 \\
-0.02 \pm 0.06 \\
-0.53 \pm .53\end{array}$ & $\begin{aligned} 25.06 & \pm 0.45 \\
157.43 & \pm 4.53 \\
19.21 & \pm 0.60 \\
116.10 & \pm 5.06 \\
13.51 & \pm 0.79 \\
64.04 & \pm 6.99\end{aligned}$ \\
\hline $\begin{array}{l}\text { tolerance - latitude } \ldots \ldots \ldots \ldots \ldots \\
\text { Adh-F - latitude } \ldots \ldots \ldots \ldots \ldots \ldots\end{array}$ & $\begin{array}{l}0.921 \\
0.923\end{array}$ & $\begin{array}{l}0.24 \pm 0.02 \\
2.22 \pm 0.17\end{array}$ & $\begin{array}{r}6.11 \pm 0.31 \\
-\quad 6.39 \pm 2.72\end{array}$ \\
\hline $\begin{array}{l}\text { tolerance }- \text { Adh-F } \ldots \ldots \ldots \\
\text { Adh-F - tolerance } \ldots \ldots \ldots\end{array}$ & $\begin{array}{l}0.894 \\
0.894\end{array}$ & $\begin{array}{l}0.10 \pm 0.01 \\
8.04 \pm 0.73\end{array}$ & $\begin{array}{r}7.49 \pm 0.35 \\
-\quad 48.54 \pm 3.18\end{array}$ \\
\hline
\end{tabular}

No correlation with longitude was observed and this parameter will not be considered further. As expected, temperature is strongly correlated with latitude, while rainfall is less dependent. Ethanol tolerance is negatively related to temperature and rainfall, as also are $A d h-F$ frequencies. Surprisingly, the biological traits are more strongly correlated with latitude than with the climatic parameters since $r$ values exceed 0.9. It therefore seemed more interesting to consider these relationships in the light of more details.

The coefficient of correlation $r$ assumes a linear relationship between 2 variables. However, the graphic plots given in figure 3 show this not to be the case, especially between latitude and $A d h-F$ frequencies. Values for French and Soviet Union populations are very homogenous over a range of 7 degrees of latitude. More Southern populations around the mediterranean sea, are more variable and exhibit a steep slope with latitude. Apparently, this steep slope can be extended by using the values obtained in South Africa, so that, over 10 degrees of latitude (40 to 30 degrees) the average frequency of the $F$ allele falls from 95 to $25 \mathrm{p}$. 100 . In tropical and equatorial localities, the frequencies are very low, less than $10 \mathrm{p}$. 100 . Only one exception concerns the population from Taï forest in Ivory Coast. For other traits, this population also exhibits 

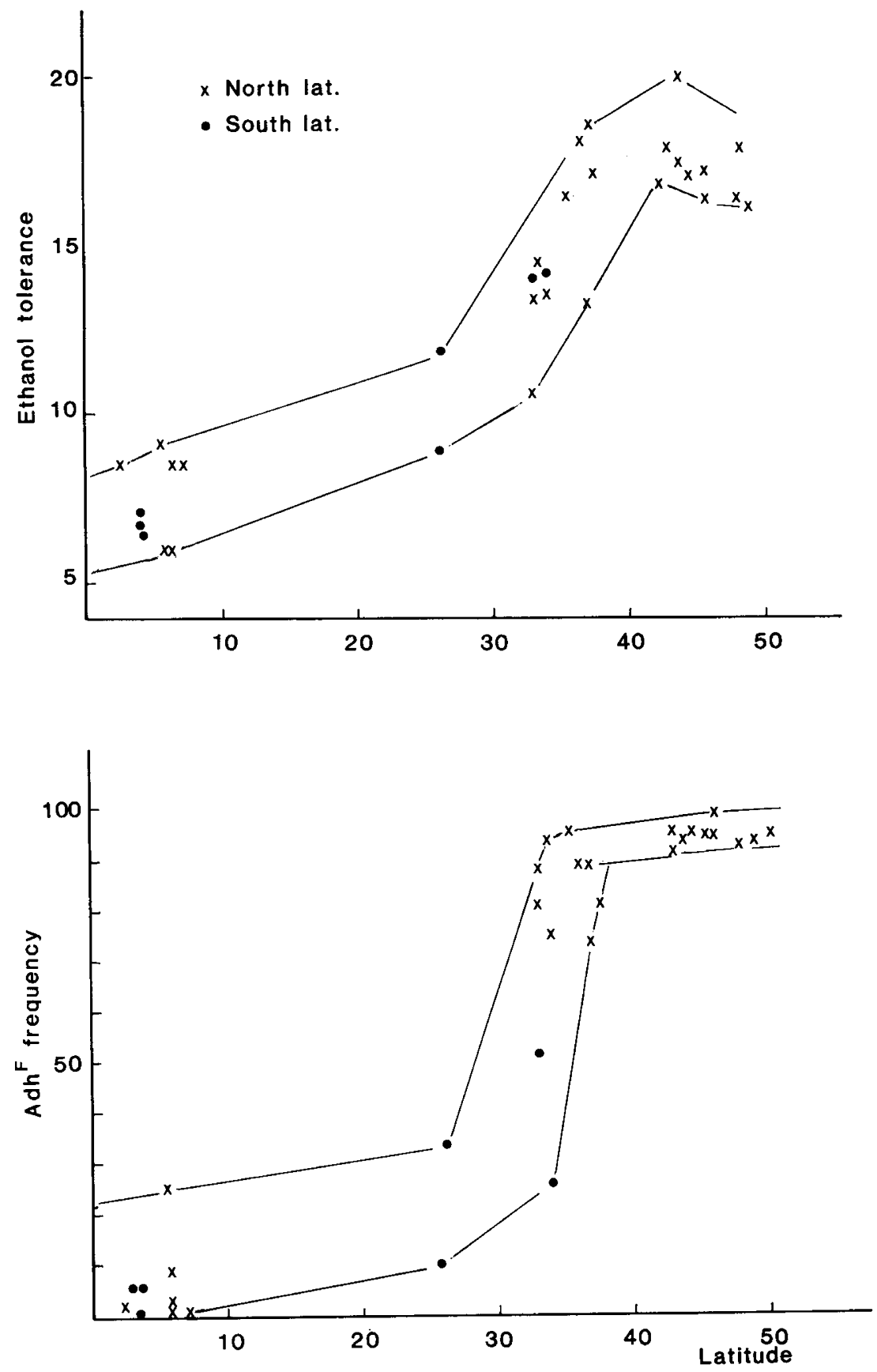

FIG. 3

Relationship between latitude and adult ethanol tolerance or Adh-F frequency. 
original and unexpected properties (DAvid et al., 1985 and unpublished observations). For the moment, we cannot state if this exception reflects some localized differentiation related to a specific habitat or some more general tendency toward the Western part of the African continent.

Variation of alcohol tolerance and $A d h$ allelic frequencies with latitude exhibit similar patterns (fig. 3). This is not surprising since both traits are highly correlated (tabl. 1). However, in this case, the regression is not statistically different from a straight line.

\section{Discussion and conclusion}

Variations in ethanol tolerance in larvae and adults are highly correlated and this result has a practical consequence : for the analysis of a natural population, the easiest way, i.e. adult testing, may be chosen even if we consider that (DAvID \& VAN Herrewege, 1983) environmental ethanol, as an ecological parameter, is more likely to exert a selective pressure during larval development. The $A d h$ gene produces a key enzyme for ethanol detoxification and molecular studies of messenger RNA have shown that the transcription of the gene does not start at the same place in larvae and adults (BenYajati et al., 1983). It is interesting to find that, in spite of this difference, the physiologies of larvae and adults which are finally under the control of the same enzymatic protein, are similar. However, such a conclusion might not be valid for other Drosophila species (McDonald \& Avise, 1976 ; David \& Van Herrewege, 1983).

Adh allelic frequency varies according to geographic parameters and especially with latitude. Previously, 3 latitudinal clines were well documented for this locus, i.e. North America (Johnson \& Schaffer, 1973), Australasia and Asia (OAKeshott et al., 1982). The present work demonstrates a similar trend between Europe and equatorial Africa, and presumably a symetrical cline in the Southern hemisphere, from the equator to South Africa. Altogether we may now consider that the tendency of the $F$ allele to increase in frequency with latitude has been observed in 5 independent geographic situations, in natural populations having very different histories (DAVID \& TSACAS, 1981) : this general phenomenon, which should be investigated in other parts of the world and especially South America, is a strong argument for assuming the adaptive significance of the clines. However, as already pointed out by OAKESHOTT et al. (1982), since all natural populations are polymorphic, some type of balancing selection is likely to exist in each locality, and the cline would correspond to a progressive shifting of the equilibrium values.

An original observation, shown in figure 3 , is that the cline observed between Europe and tropical Africa is not linear: a rapid variation occurs at intermediate latitudes, corresponding to localities with a mediterranean climate. Such a phenomenon does not exist on the East Coast of America (Johnson \& Schaffer, 1973) where the cline is obviously linear. OAKESHOTT et al. (1982) did not discuss the problem of linearity. However, considering the published data from Australasia (ANDERSON, 1981 ; OAKESHOTT et al., 1982) it appears that the frequencies can be approximately superimposed over those of figure 3 . These Australasian populations were collected between 9 and 43 degrees of latitude but most of them between 30 and $40^{\circ}$, i.e. in places with a mediterranean climate. This observation suggests the hypothesis that mediterranean countries harbor unstable populations, quite variable over short distances. 
Alcohol tolerance exhibits similar latitudinal variations as $A d h$ allelic frequencies and apparently also the "mediterranean instability». These data cannot be compared to what occurs on other continents since very few studies of ethanol tolerance are available. It seems however that, in Australia, the tolerance also increases with latitude (Parsons \& Stanley, 1981). The great variability observed around the Mediterranean sea can be contrasted with a remarkable stability in the French populations, since all the values measured on adults are between 16.1 and 17.8. Such a small range (1.7 p. 100 alcohol) may be assigned to the sampling error and to some uncontrolled variations between experiments : the genetic variation between populations, if any, must be very small. Some values which exceed 17.8 have been found so that French populations of $D$. melanogaster can no longer be considered the most tolerant. In particular the Magarach (Krimea, Soviet Union) population exhibited a tolerance of 20 p. 100 ; the test was repeated twice with similar results. This population was collected in a wine cellar and its high tolerance may reflect some very efficient ethanol selection.

The high correlation ( 0.89$)$ between $A d h-F$ frequency and ethanol tolerance raises the following question : is there any causal relationship between alcohol tolerance (itself mediated by environmental ethanol) and $A d h-F$ ? Some indirect arguments favor this hypothesis. For example we know that an active enzyme is compulsory for ethanol detoxification (DAvid et al., 1976) and that the $F$ allele produces more active protein than $S$ (DAY et al., 1974) although variations in the number of enzyme-molecules may also be involved (McDonALD et al., 1980). Numerous investigators have treated experimental populations with alcohol and, in the majority of cases, an increase of the $F$ frequency was observed (see VAN DELDEN, 1982 for a review). However, a strict relationship between the level of enzyme activity and the level of alcohol tolerance does not appear a necessity, as demonstrated by MidDleton \& KACSER (1983). Also in some cases, treating laboratory cultures with alcohol resulted in a decrease on the frequency of the $A d h-F$ allele (Gibson et al., 1979). Other environmental factors such as temperature have been considered for explaining the latitudinal cline in $A d h$ gene but with poor experimental evidence (VAN DELden, 1982). OAKeshotT et al. (1982) found that, for Australian populations, the latitudinal variation of the $F$ allele was almost entirely accounted for by $R$ max, i.e. the amount of rainfall during the wettest month of the year. But, as pointed out in that paper, the possible mechanisms underlying this relationship remain obscure.

Finally, both clines here observed seem to have an adaptive significance. Variations in ethanol tolerance may be related to some selection by environmental alcohol, although a field investigation of the amount of ethanol found in natural resources would be of great value. The causal relationship between environmental ethanol and $A d h$ polymorphism remains still more conjectural, even if we consider that the permanent tendency of the $F$ allele to increase in frequency with latitude, leaves little doubt about the adaptive significance of the cline.

Received December 18, 1985. Accepted April 30, 1986. 


\section{Acknowledgements}

We thank Mrs M. de Scheemacker-Louis, E. Pla and J. Sandrin for help in the laboratory experiments. We are also very grateful to the many people who helped in the collection of the natural populations here studied, i.e. Drs D. Anxolabehere, M. Bouletreau, Y. Carton, M. Dauvergne, B. Delay, A. Fleuriet, M. Golubovski, D. Lachaise, J. Louis, N. Menard, C. Montchamp, G. Periquet, S. Ronsseray, L. Tsacas, S. Tsakas and J. Van Alphen.

\section{References}

Anderson P.R., 1981. Geographic clines and climatic associations of Adh and $\alpha$-Gpdh gene frequencies in Drosophila melanogaster. In : Gibson J.B. \& OAKeshotr J.G. (eds), Genetic studies of Drosophila populations. Aust. Nat. Univ., Canberra, 237-250.

Benyajati C., Spoerel N., Haymerle H., Ashburner M., 1983. The messenger RNA for alcohol dehydrogenase in Drosophila melanogaster differs in its 5 end in different developmental stages. Cell., 33, 125-133.

Charles-Palabost L., Lehmann M., Merçot H., 1985. Allozyme variation in fourteen natural populations of Drosophila melanogaster collected from different regions of France. Génét. Sél. Evol., 17, 201-210.

DAvid J.R., 1982. Latitudinal variability of Drosophila melanogaster. Allozyme frequencies divergence between European and Afrotropical populations. Biochem. Genet., 20, 747-761.

David J.R., Foullnet P., Arens M.F., 1974. Comparaison de la sensibilité à l'alcool éthylique de six espèces de Drosophila du sous-groupe melanogaster. Arch. Zool. Exp. Gén., 115, 401-410.

DAvid J.R., Bocquet C., 1975. Similarities and differences in latitudinal adaptation of two Drosophila sibling species. Nature, 257, 588-590.

David J.R., Bocguet C., Arens M.F., Fouillet P., 1976. Biological role of alcohol dehydrogenase in the tolerance of Drosophila melanogaster to aliphatic alcohols : utilization of an ADHnull mutant. Biochem. Genet., 14, 989-997.

David J.R., Tsacas L., 1981. Cosmopolitan, subcosmopolitan and widespread species : different strategies within the drosophilid family (Diptera). C.R. Soc. Biogéog., 57, 11-26.

David J.R., VAN Herrewege J., 1983. Adaptation to alcoholic fermentation in Drosophila species : relationship between alcohol tolerance and larval habitat. Comp. Biochem. Physiol., 74A, 283-288.

David J.R., Capy P., Payant V., Tsakas S., 1985. Thoracic trident pigmentation in Drosophila melanogaster : differentiation of geographical populations. Génét. Sél. Evol., 17, 211-223.

Day T.H., Hillier P.C., Clarke B., 1974. The relative quantities and catalytic activities of enzyme produced by alleles at the alcohol dehydrogenase locus in Drosophila melanogaster. Biochem. Genet., 11, 155-165.

Gibson J.B., Lewis N., Adena M.A., Wilson S.R., 1979. Selection for ethanol tolerance in two populations of Drosophila melanogaster segregating alcohol dehydrogenase allozymes. Aust. $J$. Biol. Sci., 32, 387-398.

Girard P., Palabost L., Petit C., 1977. Enzymatic variation at seven loci in nine natural populations of Drosophila melanogaster. Biochem. Genet., 15, 589-599.

Johnson F.M., Schaffer H.E., 1973. Isozyme variability in species of the genus Drosophila. VII. Genotype-environment relationships in populations of Drosophila melanogaster from the Eastern United States. Biochem. Genet., 10, 149-163.

Lemeunier F., David J.R., Tsacas L., Ashburner M., 1986. The Drosophila melanogaster species group. In : Ashburner M., Carson H.L., Thompson J.M. (eds), The Genetics and Biology of Drosophila. Acad. Press, London (in press).

McDonald J.F., Avise J.C., 1976. Evidence for the adaptive significance of enzyme activity levels : interspecific variation in $\alpha-G p d h$ and Adh in Drosophila. Biochem. Genet., 14, 347 355 . 
McDonald J.F., Anderson S.M., Santos M., 1980. Biochemical differences between products of the Adh locus in Drosophila. Genetics, 95, 1013-1022.

Middleton R.J., Kacser H., 1983. Enzyme variation, metabolic flux and fitness : alcohol dehydrogenase in Drosophila melanogaster. Genetics, 105, 633-650.

Oakeshott J.G., Gibson J.B., Anderson P.R., KnibB W.R., Anderson D.G., Chambers G.K., 1982. Alcohol dehydrogenase and glycerol-3-phosphate dehydrogenase clines in Drosophila melanogaster on different continents. Evolution, 36, 86-96.

Parsons P.A., Stanley S.M., 1981. Comparative effects of environmental ethanol on Drosophila melanogaster and $D$. simulans adults including geographic differences in D. melanogaster. In : Gibson J.B., OAKeshott J.G. (eds), Genetic studies of Drosophila populations. Aust. Nat. Univ. Press, Canberra, 47-57.

Pouluk M.D., 1957. Starch gel electrophoresis in a discontinuous system of buffer. Nature, 180, 1477.

Singh R.S., HickeY D.A., DAVID J.R., 1982. Genetic differentiation between geographically distant populations of Drosophila melanogaster. Genetics, 101, 235-256.

VAN Delden W., 1982. The alcohol dehydrogenase polymorphism in Drosophila melanogaster: selection at an enzyme locus. Evolut. Biol., 15, 187-222.

Voelker R.A., Cockerham C.C., Johnson F.M., Schaffer H.Z., Mukai T., Mettler L.E., 1978. Inversions fail to account for allozyme clines. Genetics, 88, 515-527. 